\title{
Engineering and Tectonic Study of Rocks Discontinuities in the Proposed Abo-Hederya Quarry Site, Missan SE Iraq
}

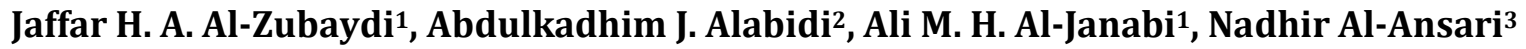 \\ ${ }^{1}$ Applied Geology Department, College of Science, University of Babylon, Babylon, Iraq \\ ${ }^{2}$ Department of Geology-Faculty of Science, University of Kufa, Kufa, Iraq \\ ${ }^{3}$ Lulea University of Technology, Lulea, Sweden \\ Email: nadhir.alansari@Itu.se
}

Received 30 July 2016; accepted 22 August 2016; published 25 August 2016

Copyright (C) 2016 by authors and Scientific Research Publishing Inc.

This work is licensed under the Creative Commons Attribution International License (CC BY).

http://creativecommons.org/licenses/by/4.0/

(c) (i) Open Access

\begin{abstract}
A detailed field survey of discontinuity (fractures) was carried out in the proposed Abo-Hederya Quarry Site, $70 \mathrm{~km}$ east Missan city, south-east of Iraq, where Al-Mukdadiya Formation (Upper Miocene-Pliocene) is exposed. The discontinuity survey was carried out in 10 stations covering the study area. At each station notes were collected about beds (lithology, thickness and orientation) and discontinuities (orientation, density, spacing, persistence and aperture). The slope stability analysis suggests that there is no real hazard area that could affect the quarry in future. Tectonic analysis demonstrates that tension fractures are common in the study area, while shear fractures (okl, hko, hol and hkl) are the less. The maximum principal stress direction in the study area is $\mathrm{N}$ $(15$ - 40) $\mathrm{E}$, which is compatible with the regional tectonic stress in the area.
\end{abstract}

\section{Keywords}

Discontinuity, Fatha Formation, Missan, Iraq

\section{Introduction}

The stability of rock slopes is significantly influenced by the structural setting of the rock in which the slope is excavated which refers to naturally occurring breaks in the rock such as bedding planes, joints and faults which are naturally called discontinuities. The properties of discontinuities relative to stability include orientation, persistence, roughness and infilling [1].

The main aims of the present study are identifying the regional stresses led to these discontinuities, assess- 
ment of the effect of rock discontinuities (orientation, density, spacing, persistence, and aperture) on rock slope stability and the influence of rock slope stability on the proposed Abo-Hederya quarry that affects the safety of the quarry.

\section{The Study Area}

The study area is located in Abo-Hederya (longitude $47^{\circ} 19^{\prime} 42.9^{\prime \prime} \mathrm{E}$, and latitude $23^{\circ} 26^{\prime} 28.2^{\prime \prime} \mathrm{N}$ ) proposed quarry in Missan Governorate $95 \mathrm{~km}$ east of Amara city within Mukdadiya Formation (Figure 1).

The exposed formation in the study area is Mukdadiya formation. The name Mukdadiya formation was used by [2] to replace the Lower Bakhtiari formation [3]. Mukdadiya (Lower Bakhtiari) Formation comprises up to 2000 meters of fining upwards cycles of gravely sandstone, sandstone and red mudstone. The Formation was deposited in fluvial environment in a rapidly subsiding foredeep basin. The age based on the vertebrate fauna is Late Miocene [4]. The lower contact is recognized lithologically by the first occurrence of the pebbly sands. It is distributed mostly in the Foothill Zone. The upper contact of the formation that overlain Mukdadiya Formation is diachronous [5]; it is recognized lithologically by the appearance of the first thick (more than 1 meter) conglomerate horizon [6]. In the study area the upper contact of Al-Mukdadiya formation is an erosional surface (angular unconformity surface), with the overlain quaternary deposits.

The study area is located within Himreen subzone, foothill zone, which is a part of unstable shelf according to tectonic map of Iraq (1996) (Figure 2) [5] [7]. It is in an extension of asymmetrical Himreen anticlines, with

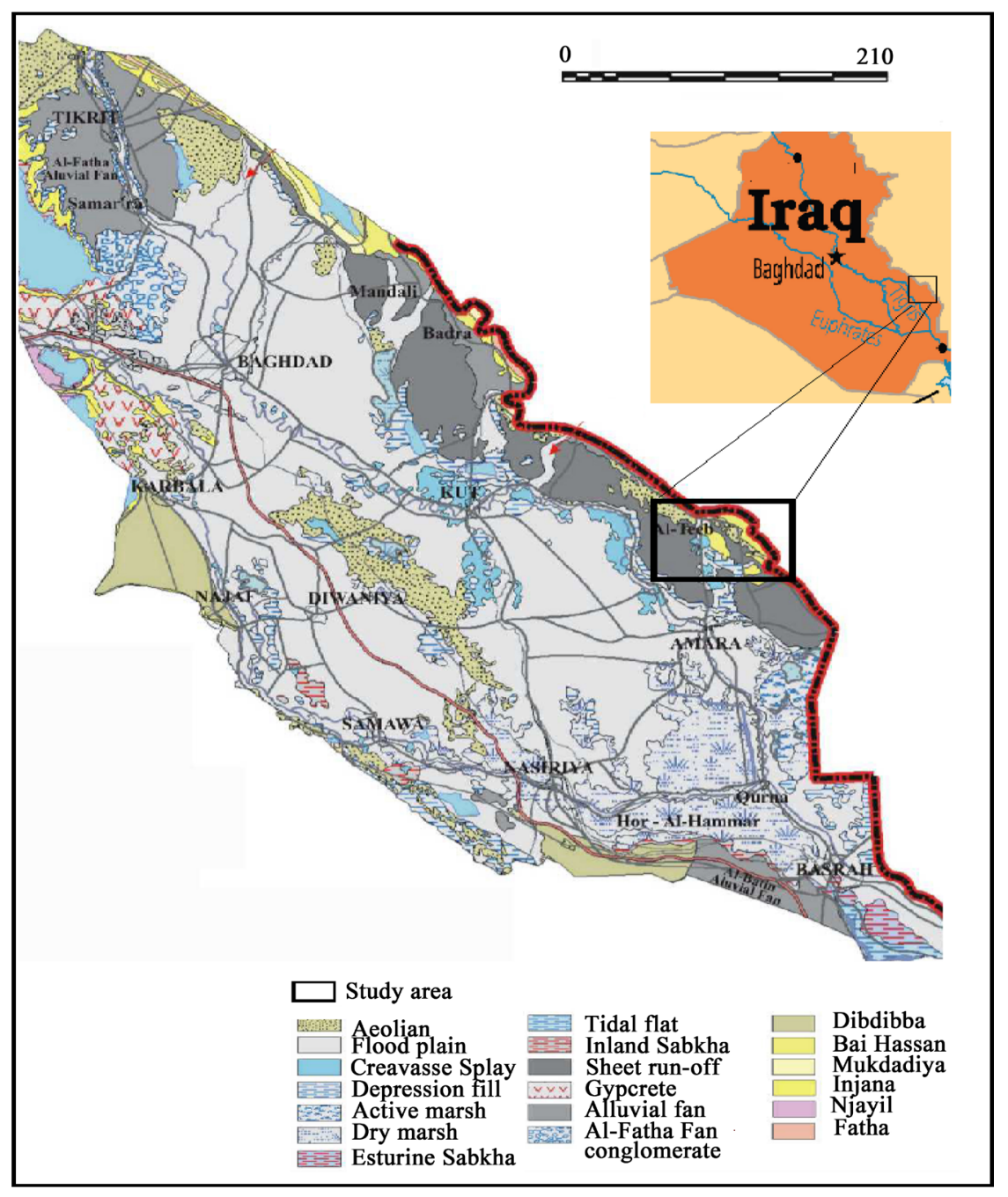

Figure 1. Location and geological map of study area [8]. 


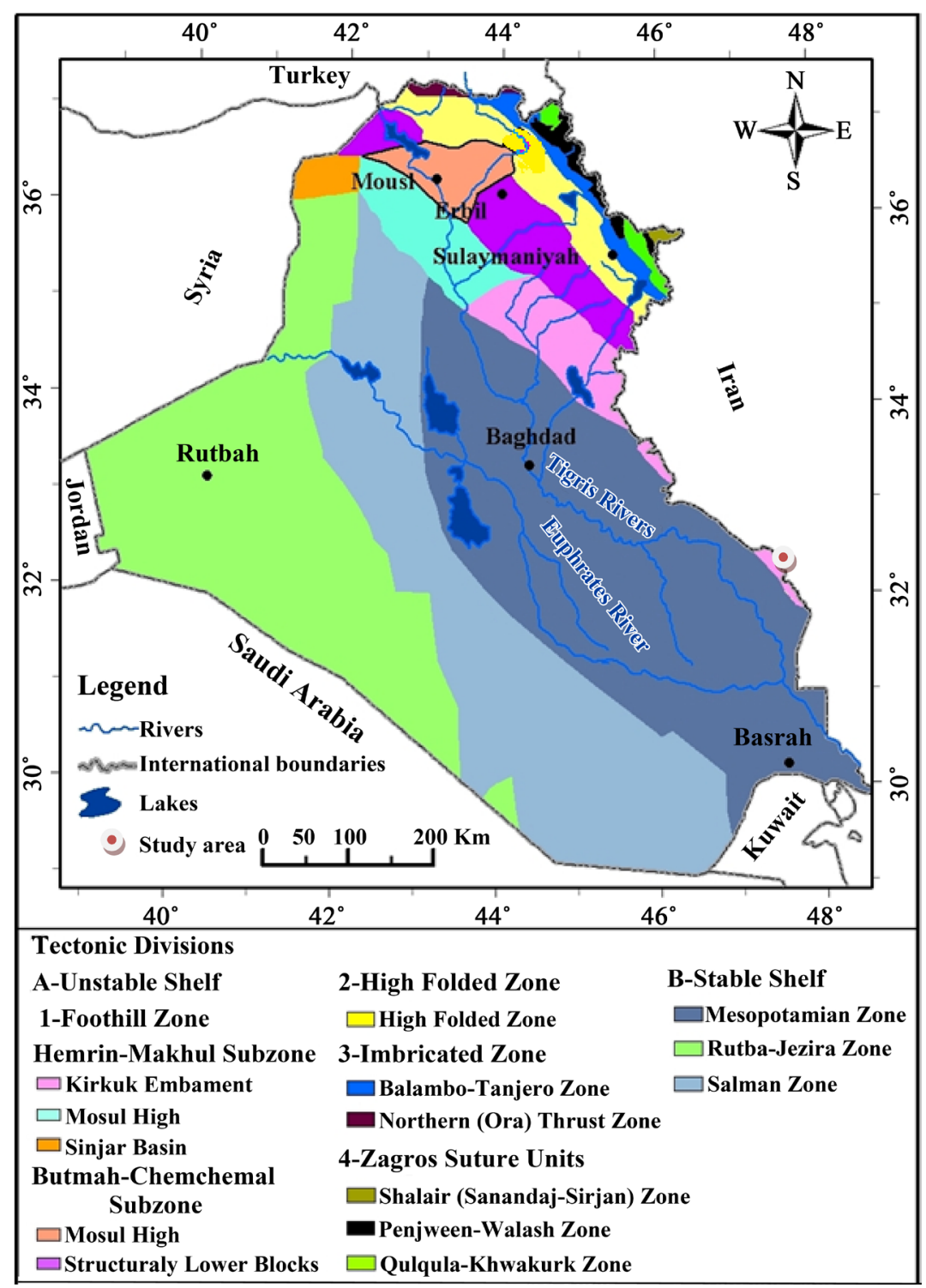

Figure 2. Tectonic map of Iraq (modified after [3]).

fold axis trending NW-SE, and bounded between two thrust faults with NW-SE direction (Figure 1), as a result of the collision between the Arabian and Iranian plates. The dip of the beds has an average value ranging from 20 to $8^{\circ}$ because of their location near the hinge area of the fold as in Figure 1.

\section{Methodology}

Field work was carried out for 8 days, from 7th to 14th Feb., 2015. It covered the discontinuity, lithology, and geomorphologic features survey. It was carried out in 10 stations. The area of each station was not less than 2.5 $\times 2.5 \mathrm{~m}$, while the location and distribution of these stations were mainly based on the availability of exposures and the importance of engineering and structural position. At each station notes were collected for beds (lithology, thickness and attitude) and discontinuities (orientation, density, spacing, persistence, and aperture).The office work of the present study included calculating, representing and analyzing of the field data.

\section{Geomorphologic Features of Study Area}

The most common geomorphologic features found in the studied area were as follows: 
Strike Ridges: Strike Ridges are Common within Mukdadiya as in Figure 3(a).

Rill Erosion: This feature is more effective and influential on the soft rocks that cover large areas (Figure $3(\mathrm{~b}))$.

Gully Erosion: This feature is effective on solid rocks like Sandstone (Figure 3(c)).

Badland Erosion: This type of sculpture is common in Mukdadiya Formation composed of complex valleys and irregular lands (Figure 3(d)).

Mesa: Mesa formed when the beds are horizontal or near to horizontal (or sub horizontal) as in Figure 3(e).

Sand Sheets: They are scattered among different part of the studied area as in Figure 3(f).

\section{Discontinuities}

Discontinuity is a general term for any mechanical break that has zero or relatively low tensile strength, it is a collective term that includes feature such as joint (a barren closed discontinuity on which no measurable slip is observed), vein (a discontinuity in which visible mineral infill took place), fissure (a discontinuity with a void space), fault (a discontinuity along which a detectable slip has occurred), and bedding plane (a discontinuity that separates the adjacent rock beds) [9]-[11]. The discontinuities strongly effect the mechanical and hydrological properties of a rock mass, in term of its strength, deformability, stability, porosity, and permeability [8], accordingly, the discontinuities play a major role in the design and safety of civil works [10] and the occurrence and movement of ground water and hydrocarbons [12] (H. There are many field and laboratory parameters which can be used to evaluate any site under study. The type of these parameters depends on the purpose of the study [9]. In the present study only five field parameters were used. These are: orientation, density, spacing, persistence, and aperture. The parameters have direct relations to the geotechnical aspects of the study area.

\subsection{Discontinuity Orientation}

Discontinuity orientation is the attitude of discontinuity in space. It could show grouping into sets (group of parallel discontinuities that maintain their orientation over considerable area) and system (applied to two intersecting discontinuity sets with relatively fixed angle of intersection) [9].

The discontinuity orientation can be described by the dip of the line of steepest inclination measured [13] [14],
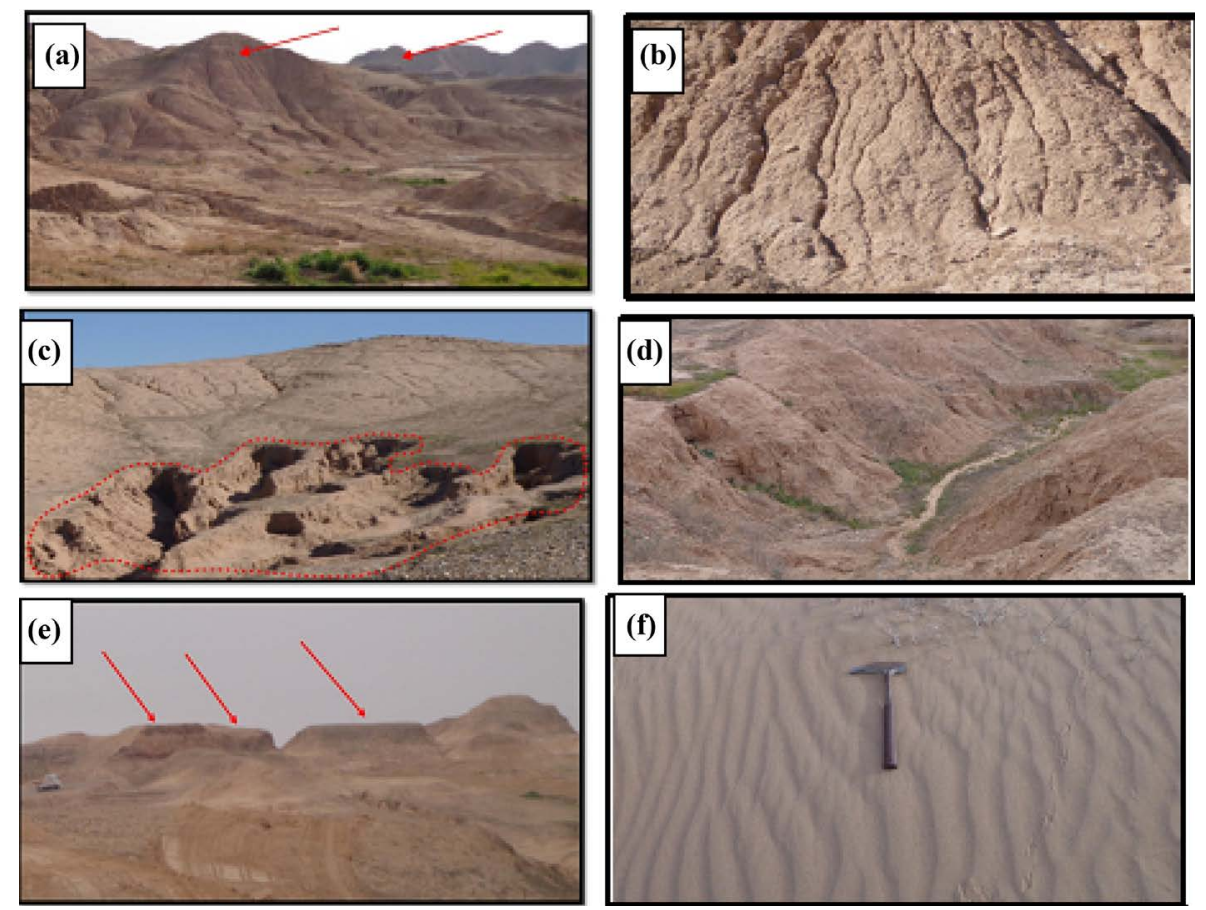

Figure 3. Geomorphologic Features of study area ((a) Strike Ridges; (b) Rill Erosion; (c) Gully Erosion; (d) Badland Erosion; (e) Mesa; (f) Sand sheet). 
from horizontal, and by the dip direction measured clock wise from true north. Example: dip direction/dip angle $\left(025^{\circ} / 45^{\circ}\right)$. The average readings of the discontinuity orientations in the stations of the study area were designated in Table 1 as $1 ; 2 ; 3 ; 4 ; 5 ; 6 ; 7 ; 8 ; 9 ; 10$. Discontinuity (fracture) analysis according to the principal tectonic axes was done to detect the geometrical and genetic relationship with the stresses in the region. Fractures were representative in the form of shear fracture sets ( $\mathrm{okl}$, hko, hol and hkl) and extension fracture set (ac).

The common discontinuity sets are persistently developed and are characterized by being normal to the bedding, while the less common discontinuity sets are characterized by being inclined at various degrees to the bedding (Figures 4(a)-(i)). Stereograms (stereographic projection) of orientations of discontinuities groups using stereonet ver. 8.9 software were done as shown in (Figures 5(a)-(j)). From stereographic projection, indicates

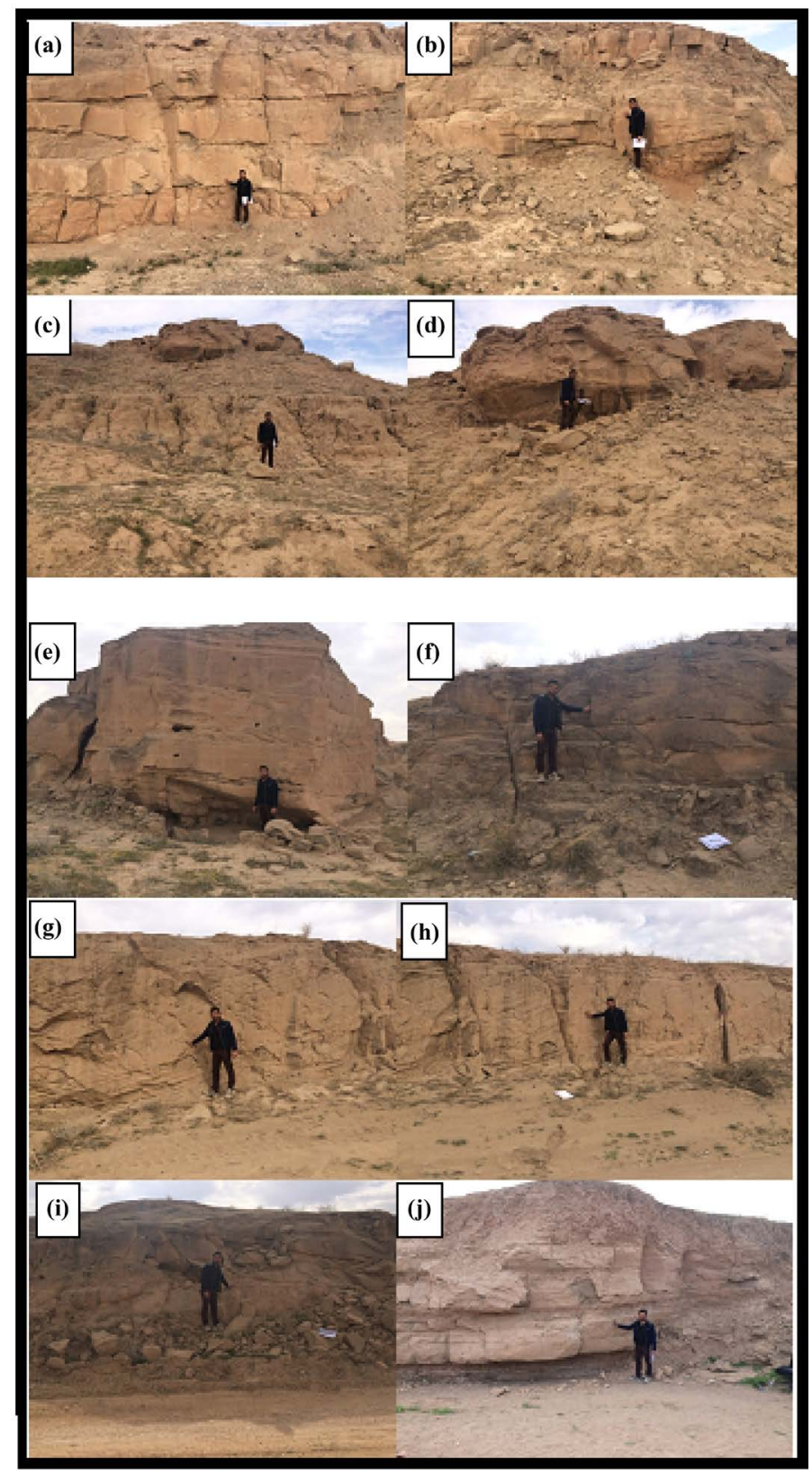

Figure 4. (a) The dominant fractures in station; (b) The dominate fractures in station; (c) The dominant fractures in station; (d) The dominant fractures in station; (e) The dominant fractures in station; (f) The dominant fractures in station; (g) The dominant fractures in station; (h) The dominant fractures in station; (i) The dominant fractures in station; (j) The dominant fractures in station. 
that there are no conjugate systems of fractures in the same station to make use of it in finding the maximum principal stress. Therefore, tension set fractures (ac) were considered, which always accompanist to conjugate system and resulting from the same maximum stress, to find the maximum principal stress in the study area which represent the regional stress in the area. It was found that the maximum principal stress direction in the study area was between N15E to N40E.

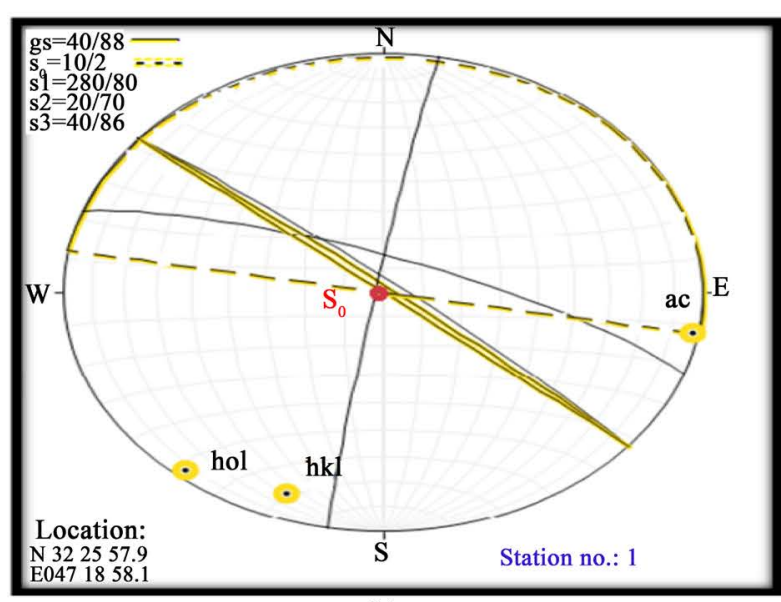

(a)

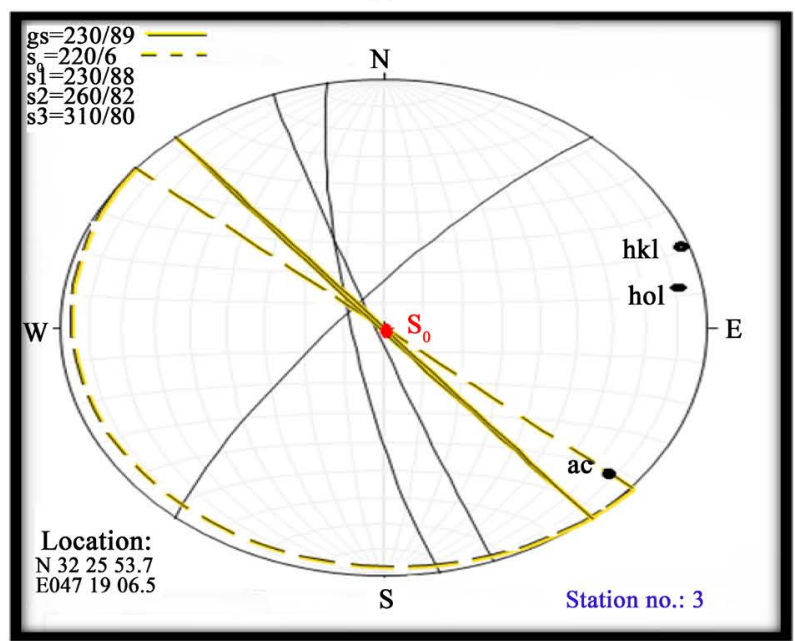

(c)

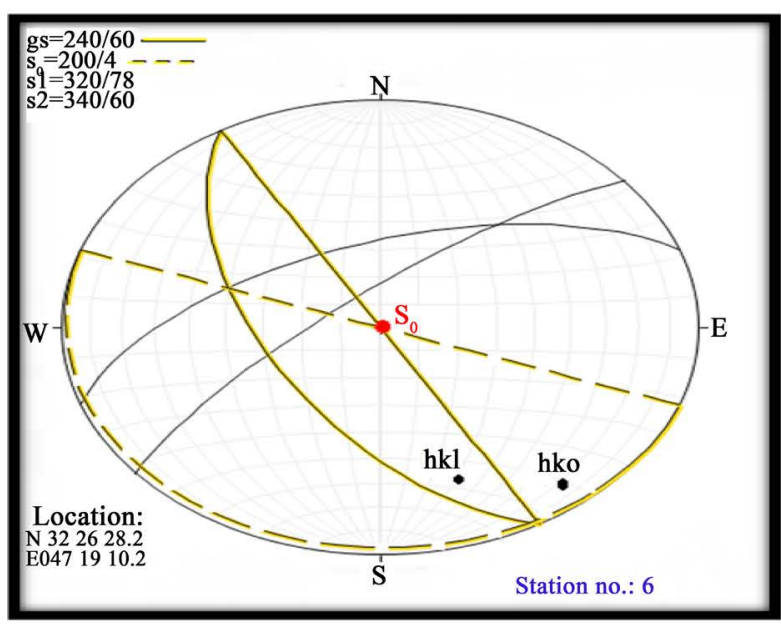

(e)

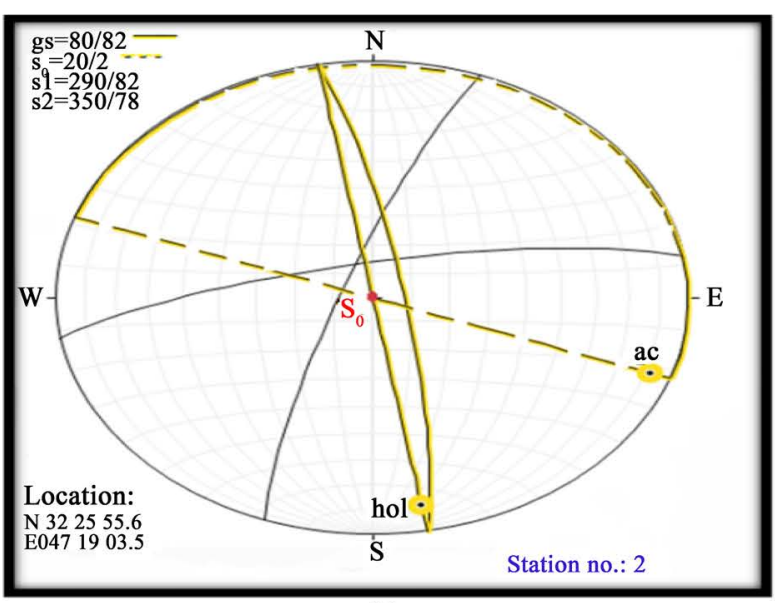

(b)

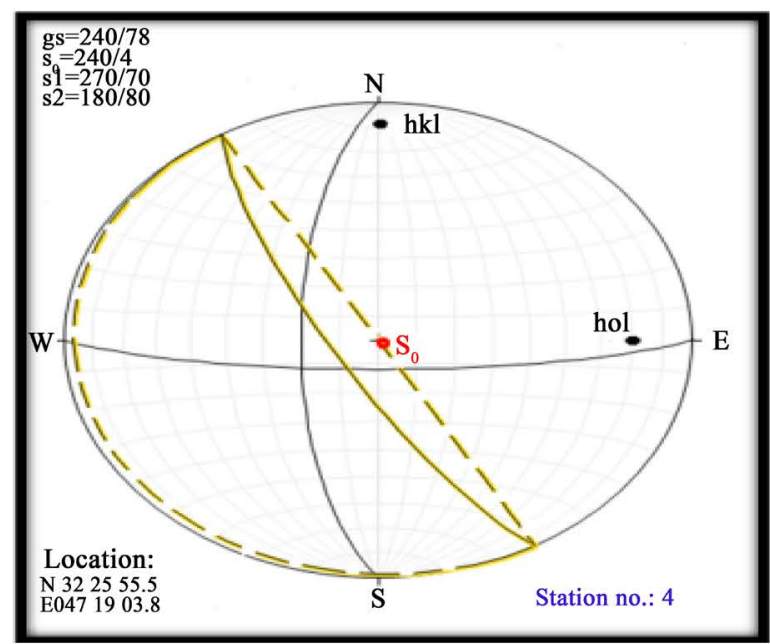

(d)

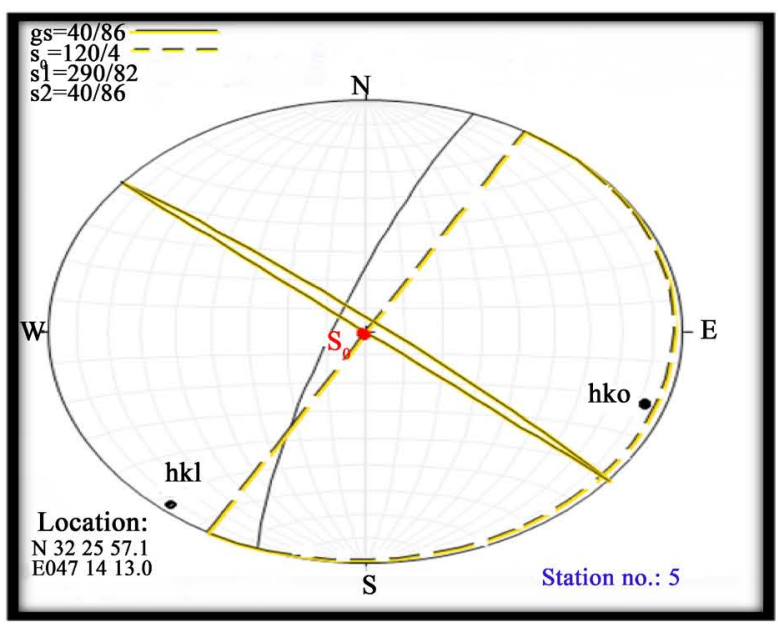

(f) 


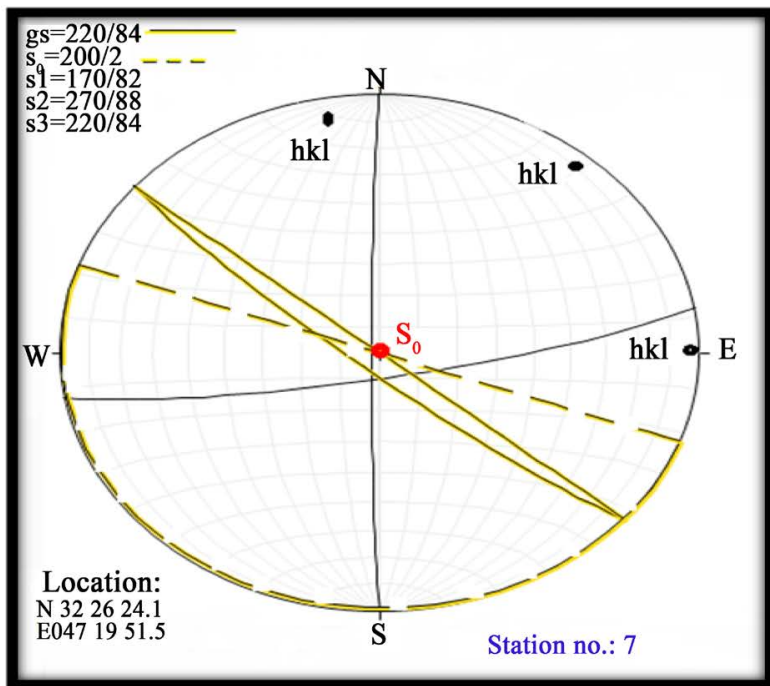

(g)

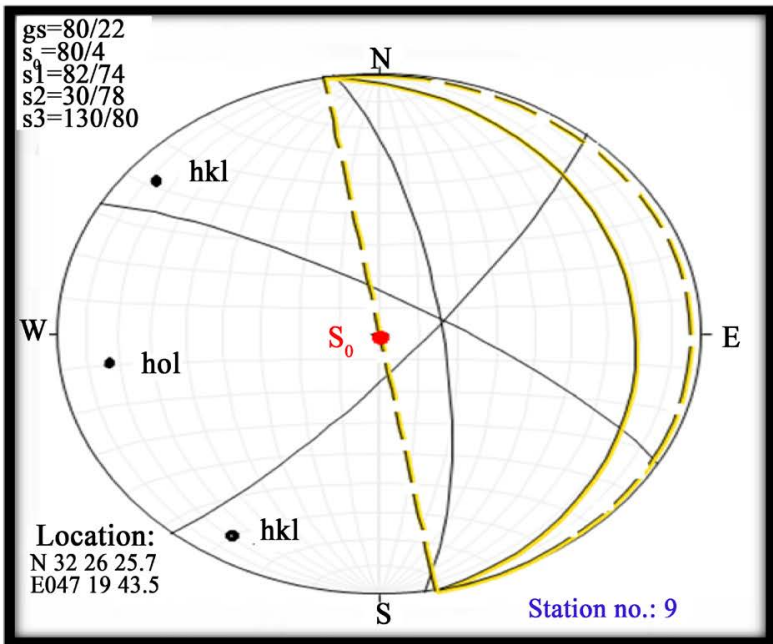

(i)

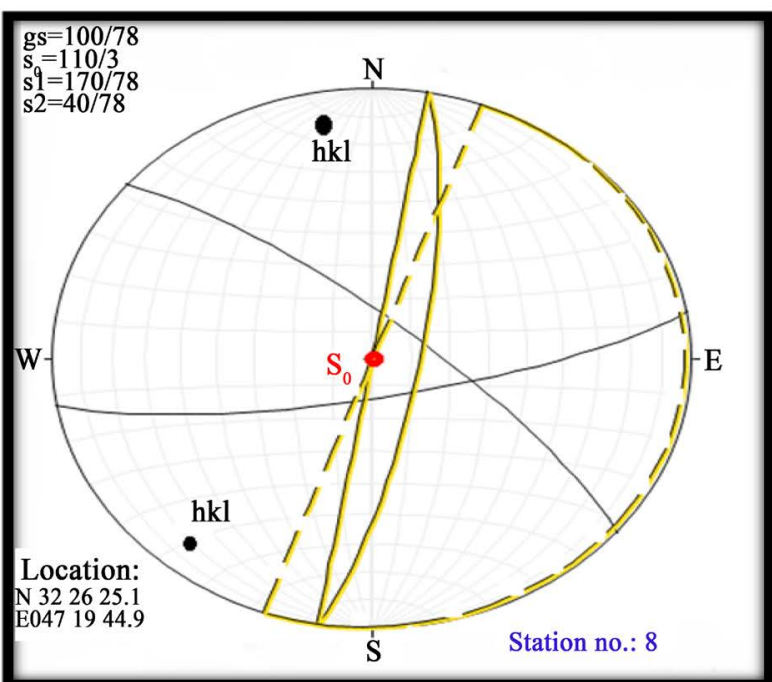

(h)

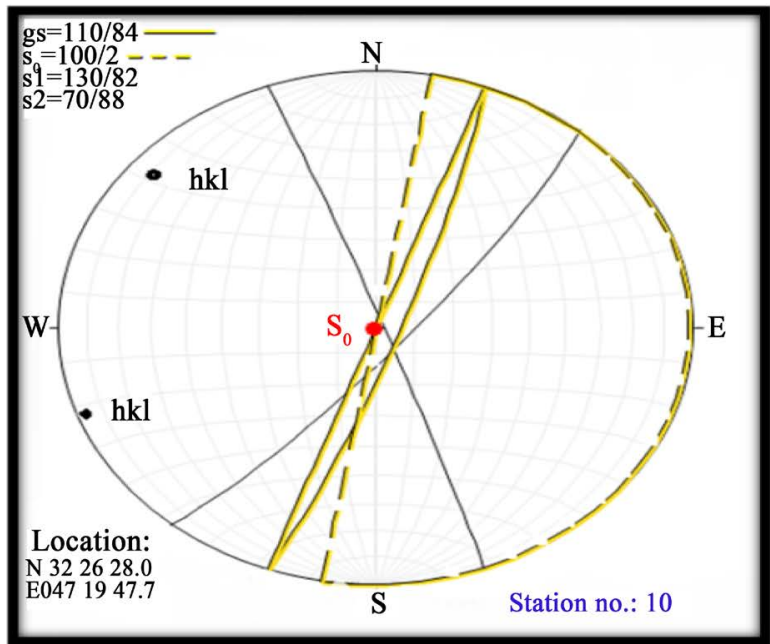

(i)

Figure 5. Stereogram of orientations of discontinuities (fractures) groups in stations (1, 2, 3, 4, 5, 6, 7, 8, 9, and 10).

\subsection{Discontinuity Density (d)}

It is the cumulative trace length of discontinuities in a given area regardless of their orientation [15] [16] (Figure 6).

In the present study, it was measured within an area about $2.5 \times 2.5 \mathrm{~m}$ of each field station using the following equation:

$$
d=\frac{1}{A} \times \sum_{i=1}^{N} L i
$$

where:

$d=$ discontinuity density

$A=$ area of discontinuity density measurement $\left(\mathrm{m}^{2}\right)$

$i=$ discontinuity number

$N=$ whole number of discontinuities within A

$L=$ discontinuity length (m).

It showed wide variation (Table 1) and it was used to evaluate the porosity and permeability of the exposed rocks of the study area. 


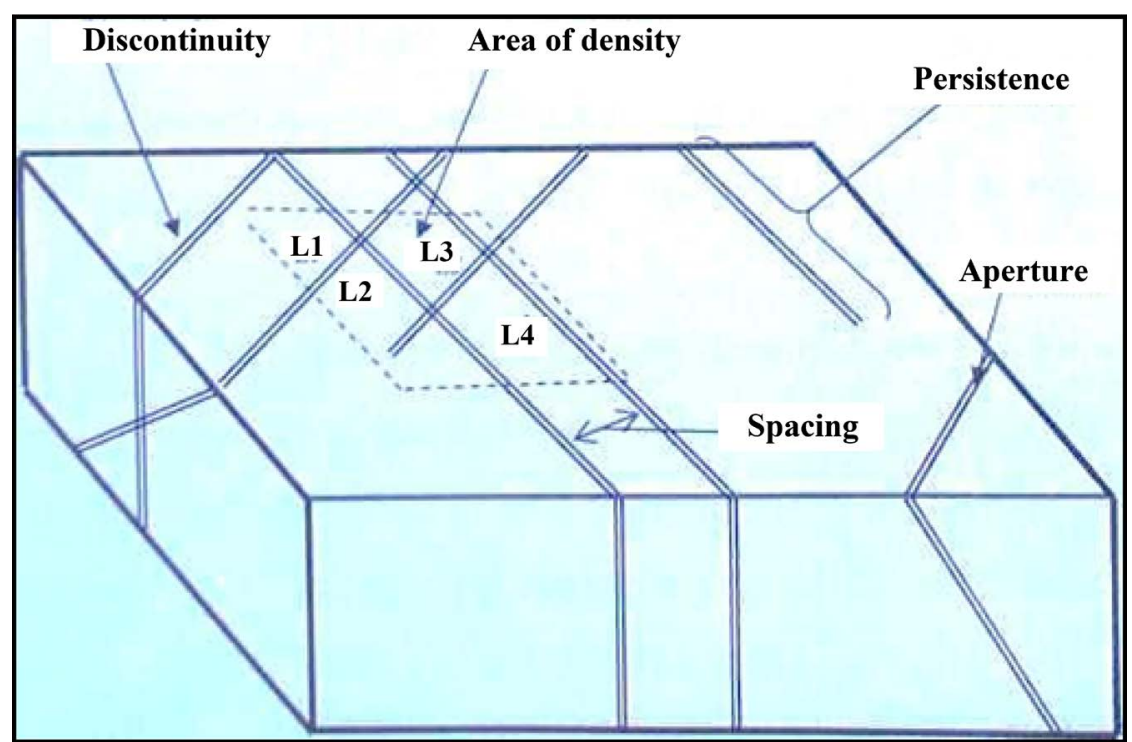

Figure 6. Schematic block diagram shows the discontinuity spacing, persistence and aperture modified after [9] [16].

Table 1. The average readings of the discontinuities in the study area.

\begin{tabular}{|c|c|c|c|c|c|c|c|}
\hline $\begin{array}{l}\text { Station } \\
\text { No. }\end{array}$ & Location & $\begin{array}{l}\text { Elevation } \\
(\mathrm{m})\end{array}$ & $\begin{array}{l}\text { Discon. } \\
\text { Density } \\
\text { (m) }\end{array}$ & $\begin{array}{l}\text { Discon. } \\
\text { Spacing } \\
(\mathrm{m})\end{array}$ & $\begin{array}{l}\text { Discon. } \\
\text { Persistence } \\
\text { (m) }\end{array}$ & $\begin{array}{l}\text { Discon. } \\
\text { Aperture } \\
(\mathrm{cm})\end{array}$ & $\begin{array}{c}\text { Discon. } \\
\text { Orientation } \\
\text { (S1, S2, S3) }\end{array}$ \\
\hline 1 & $\begin{array}{c}\text { N32 } 2557.9 \\
\text { E047 } 1858.1\end{array}$ & 29 & 2.2 & 1.2 & 5 & 1 & $114 / 84$ \\
\hline 2 & $\begin{array}{l}\text { N32 } 2555.6 \\
\text { E047 } 1903.5\end{array}$ & 32 & 1.1 & 1 & 2 & 1.5 & $320 / 80$ \\
\hline 3 & $\begin{array}{c}\text { N32 } 2553.7 \\
\text { E047 } 1906.5\end{array}$ & 31 & 1.4 & 0.7 & 4 & 0.9 & $266 / 84$ \\
\hline 4 & $\begin{array}{c}\mathrm{N} 322555.5 \\
\text { E047 } 1909.8\end{array}$ & 36 & 0.8 & 0.6 & 2.5 & 1 & $225 / 75$ \\
\hline 5 & $\begin{array}{c}\text { N32 } 2557.1 \\
\text { E047 } 1913.0\end{array}$ & 28 & 1.2 & 1.3 & 3 & 2.1 & $165 / 84$ \\
\hline 6 & $\begin{array}{c}\text { N32 } 2628.2 \\
\text { E047 } 1910.2\end{array}$ & 30 & 0.6 & 1.1 & 1 & 0.8 & $330 / 69$ \\
\hline 7 & $\begin{array}{c}\text { N32 } 2624.1 \\
\text { E047 } 1951.5\end{array}$ & 33 & 0.9 & 0.4 & 5 & 1.2 & $220 / 85$ \\
\hline 8 & $\begin{array}{l}\text { N32 } 2625.1 \\
\text { E047 } 1944.9\end{array}$ & 30 & 1.1 & 1.2 & 2 & 0.9 & $105 / 78$ \\
\hline 9 & $\begin{array}{c}\text { N32 } 2625.2 \\
\text { E047 } 1943.5\end{array}$ & 29 & 1.3 & 0.5 & 2 & 1.3 & $81 / 78$ \\
\hline 10 & $\begin{array}{l}\mathrm{N} 322628.0 \\
\mathrm{E} 0471947.7\end{array}$ & 29 & 1.1 & 2.2 & 2 & 2.0 & $100 / 85$ \\
\hline
\end{tabular}

\subsection{Discontinuity Spacing}

Discontinuity spacing is the perpendicular distance between adjacent discontinuities [9]. Discontinuity spacing is one of the most important parameters because of its direct influence on rock slope stability and intact rock block size [9] [17]. In the present study, the average spacing of each discontinuity set was measured at each station, and then the average spacing of discontinuities was computed for each station (Table 1).

\subsection{Discontinuities Persistence}

Discontinuities persistence is the trace length of discontinuities as observed on the surface of exposures and it is 
one of the most important rock mass parameters, because of its direct influence on rock slope stability and quarry. In the present study, the average persistence of discontinuity was measured for each station (Table 1 ).

\subsection{Discontinuities Aperture}

Discontinuities Aperture is the perpendicular distance between adjacent rock walls discontinuities [9] [18] [19]. The discontinuities aperture was measured for each discontinuities set. Next, the averages of apertures were found for all the observed discontinuities at each station (Table 1). The values of discontinuities aperture were increasing toward the center and decreasing on the top of the hills between the valleys.

\section{Conclusions}

Abo-Hederya is an arid area where wind is considered as principal geomorphological factor influencing rock slope geomorphology. Aeolian differential erosion acting on weak strata is forming overhanging unstable slopes.

The most common fractures have high dip angle (sub vertical) therefore they act as back release surfaces (BRS), lateral release surfaces (LRS) or composite back release surfaces (CBRS) but not as sliding surfaces. Their spacing and orientation also determine the size and shape of the failed rock blocks.

The high or low values of the discontinuities parameters have direct relationship with the structural position of the study area.

The slope stability analysis suggests that the different discontinuities sets have direct influence on slope failure in the study area. Nevertheless slope failure is limited in size distribution and has no much hazard on the quarry itself.

Fracture analysis reveals the geometrical and genetic relationship with the principal tectonic stresses, and it indicates that the maximum principal stress causing these fractures is directed N15 - 40E which is compatible with the regional stress resulting from Arabian plate motion towards NE. It has been found that tension fractures are common in the study area, while shear fractures are relatively less. This might be related to the structural position where the area is on the extension of the fold axis area.

The main stress in study area is compression and there might be some local stresses which have been represented in the form of tension fractures set (ac) and shear fractures sets (hko, hol and hkl).

\section{References}

[1] Wyllie, C. and Mah, W. (2004) Rock Slope Engineering Civil and Mining. In: Hoek, E. and Bray, J.W., Eds., Rock slope Engineering, Taylor \& Francis Group, London and New York, 431 p.

[2] Jassim, S.Z., Karim, S.A., Basi, M., Al-Mubarak, M.A. and Munir, J. (1984) Final Report on the Regional Geological Survey of Iraq. Vol. 3, Stratigraphy, Report Geological Survey of Iraq.

[3] Jassim, S.Z. and Goff, J.C. (2006) Geology of Iraq. Czechrepublic, Brno, 341 p.

[4] Bellen, R.C., Dunington, H.V., Wetzal, R. and Morton, D.M. (1959) Lexique Stratigraphy International, Asie, Fascicle.10a, Iraq. Center National de la Recherghes Scientifique, Paris, 333 p.

[5] Buday, T. (1980) The Regional Geology of Iraq, Vol 1: Stratigraphy and Paleogeography. Publications of Geological Survey of Iraq, Baghdad, 445 p.

[6] Omar, A.A. (2005) An Integrated Structural and Tectonic Study of the Bina Bawi-Safin-Bradost Region in Iraqi Kurdistan. PhD Thesis, Salahaddin University, Erbil, 314 p. (Unpublished)

[7] Al-Kadhimi, J.M.A., Sissakian, V.K., Sattar, A.F. and Deikran, D.B. (1996) Tectonic Map of Iraq. 2nd Edition, Geo Survey, Baghdad, Iraq.

[8] GEOSURV (1993) Geological map of Ali Al Gharby. Publications of Geological Survey, Iraq.

[9] ISRM (International Society for Rock Mechanics) (1978) Suggested Methods for the Quantitative Description of Discontinuities in Rock Masses. International Journal of Rock Mechanics and Mining Sciences \& Geomechanics Abstracts, 15, 319-368.

[10] Sens, Z. and Kazi, A. (1984) Discontinuities Spacing and RQD Estimates from Finite Length Scanline. International Journal of Rock Mechanics and Mining Sciences \& Geomechanics Abstracts, 3, 203-212.

[11] Sasowsky, I.D. (2001) Structural Effects on Carbonate Aquifers. Karsts Water Institute, Special Publication No. 5, Charles Towy, 38-42.

[12] Henning, P.H., Olson, J.E. and Thompson, L.B. (2001) Combining Outcrop Data and Three Dimensional Structure 
Models to Characterize Fractured Reservoirs (and Example from Wyoming). American Association of Petroleum Geologists AAPG Bulletin, 84, 830-849.

[13] Cruden, D.M. and Hu, X.Q. (1994) Toppling on Underdip Slope in the Higwood Pass Alberta, Canda. Quarterly Journal of Engineering Geology, 27, 57-68. http://dx.doi.org/10.1144/GSL.QJEGH.1994.027.P1.08

[14] Ramamaurthy, T. (2008) Engineering in Rocks for Slopes. Foundation and Tunnels, New Delhi, 357 p.

[15] Hoek, H. and Bray, J.W. (I981) Rock Slope Engineering. 3rd Edition, Institution of Mining and Metallurgy, London, $358 \mathrm{p}$.

[16] Davis, G.H. and Reynolds S.J. (1996) Structural Geology of Rock and Regions. John Wiley and Sons Inc., New York, $287 \mathrm{p}$.

[17] Goodman, R.E. and Bray. J.W. (1976) Toppling of Rock Slopes. Proceedings of the Specialty Conference on Rock Engineering for Foundations and Slopes, 2, 201-234.

[18] De Frietas, M.H. and Watters, R.J. (1973) Some Field Examples of Toppling Failures. Geotecnique, 23, $495-514$. http://dx.doi.org/10.1680/geot.1973.23.4.495

[19] Evans, R.S. (1981) An Analysis of Secondary Toppling Rock Failures the Stress Redistribution Method. Quarterly Journal of Engineering Geology, 14, 77-86. http://dx.doi.org/10.1144/GSL.QJEG.1981.014.02.01

\section{Submit or recommend next manuscript to SCIRP and we will provide best service for you:}

Accepting pre-submission inquiries through Email, Facebook, LinkedIn, Twitter, etc.

A wide selection of journals (inclusive of 9 subjects, more than 200 journals)

Providing 24-hour high-quality service

User-friendly online submission system

Fair and swift peer-review system

Efficient typesetting and proofreading procedure

Display of the result of downloads and visits, as well as the number of cited articles

Maximum dissemination of your research work

Submit your manuscript at: http://papersubmission.scirp.org/ 